\title{
КНИЖНАЯ КУЛЬТУРА
}

DOI: $10.15372 / \mathrm{HSS} 20150401$

УДК 821.161 .1

\author{
Л.В. ТИТОВА
}

\section{ДВЕ ВЕРСИИ ПОСЛАНИЯ ДЬЯКОНА ФЕДОРА ИОАННУ АВВАКУМОВИЧУ}

\author{
Любовь Васильевна Титова, \\ канд. филол. наук, старший научный сотрудник, \\ Институт истории СО РАН, \\ РФ, 630090, Новосибирск, ул. Николаева, 8, \\ e-mail: titova istochnik@mail.ru
}

В статье предпринят анализ полемического Послания дьякона Федора сыну протопопа Аввакума Иоанну о священстве, написанного им от имени всех пустозерских узников (протопопа Аввакума, инока Епифания и попа Лазаря). Оъясняются причины появления краткого варианта Послания, приписываемого протопопу Аввакуму. На основе текстологического анализа дается характеристика этой компилятивной версии Послания, представляющей собой тщательную выборку из «епистолии» дьякона Федора к Иоанну Аввакумовичу с использованием смягченного Аввакумовского варианта толкования 13-й главы Апокалипсиса. Цель статьи - охарактеризовать обе версии этого текста о священстве, очень важного в идеологическом плане для старообрядчества в целом, о чем свидетельствует широкое использование его старообрядцами в XVIII в. при составлении полемических сочинений в защиту староверия.

Ключевые слова: Послание о священстве, полемический текст, старообрядчество, текстология, дьякон Федор, протопоп Аввакум

\section{L.V. TITOVA}

TWO VERSIONS OF THE DEAN FYODOR'S EPISTLE TO IOANN AVVAKUMOVICH

\author{
Lyubov V. Titova, \\ Candidate of Philology, Senior Researcher, \\ Institute of History SB RAS, \\ 8, Nikolaeva Str., Novosibirsk, 630090, Russia, \\ e-mail: titova istochnik@mail.ru
}

The article deals with one of the ideologically most significant Old-Believers' texts - Epistle of Dean Fyodor to the Archpriest Avvakum's son Ioann (John) about the priests who had accepted the reforms of Patriarch Nikon. This work was written by the Dean Fyodor in the summer of 1669 on behalf of all Pustozersk prisoners in response to Ioann's question about the newly ordained priests. For the whole Old-Believers' world this writing served as a guide to action explaining how to behave toward the priests installed by Patriarch Nikon after he was removed from a position of Patriarch.

Along with the answers given by the Pustozersk prisoners to the questions about priests it also includes Fyodor's interpretation of the 13 Chapter of Apocalypse focused on his reflections on "the horns of Antichrist" who will cause Russia's last "renunciation of faith": "And from that time on it will be more bitter owing to the ungodly tsars: they are horns of Antichrist... The Divine saw two horns coming up out of the earth: one of them already exists; after it there will be another one, accomplice of the evil". By the "horn that already exists" the Dean Fyodor meant the Tsar Aleksey; Fyodor repeatedly called him "an evil horn" and "Antichrist". In Fyodor's letter there is no personification of the "second horn", however the text is clearly stating that it will also be a Tsar, "accomplice of the evil", who will come after Aleksey Mikhailovich.

Avvakum's interpretation of the same chapter of Apocalypse is quite different from that proposed by Fyodor: "The beast has two horns - it marks two powers: one is a winner, another is an accomplice". Aleksey is assigned the role of only an "accomplice", while in Fyodor's interpretation he was presented as the main bearer of evil. Avvakum's interpretation of Patriarch Nikon and Tsar Aleksey as two horns of Antichrist was accepted by some of the Old-Believers. This has been witnessed by creation of a new version of "The Epistle Addressed to a Certain Ioann", compilatory in nature. 
Its textual analysis showed that it contains only abstracts from the Dean Fyodor's "Epistle" with a milder variant of Avvakum's interpretation of the 13th chapter of Apocalypse. The article proves that "The Epistle Addressed to a Certain Ioann" attributed to Avvakum was compilatory in nature. The author characterizes both texts and determines the textual evolution of this Old-Believers' ideologically significant document.

Key words: Epistle about priesthood, polemical text, Old Belief, textology, Dean Fyodor, Archpriest Avvakum.

«Послание в Москву из Пустозерска», впервые опубликованное Н.И. Субботиным в 6-м томе «Материалов для истории раскола за первое время его существования» ${ }^{1}$ [1, с. 60-79], адресовано старшему сыну Аввакума, заключенному в земляной тюрьме на Мезени. Оно было написано дьяконом Федором летом 1669 г. в ответ на вопрос Иоанна о новопоставленных попах. Находясь в пустозерской ссылке с 1668 г. и отвечая в письме Иоанну на вопрос, волнующий весь старообрядческий мир, о том, как надо теперь после того, как Никона лишили патриаршества, относиться к священникам, поставленным самим Никоном или архиереями, принявшими никоновскую церковную реформу. Это послание Федора было отправлено из Пустозерска на Мезень (для дальнейшей отправки в Москву) $)^{2}$.

Послание Федора к Иоанну носило коллективный характер, который подчеркнут и в его названии. В рукописях это сочинение надписывается по-разному, но наибольшее количество списков сохранило следующий заголовок: «Список с епистолии великих отцов и страдальцев за святую соборную и апостольскую церковь, еяже должно всякому о Христе живущему прочитати и творити, и да угоден будет Богови, занеже несть ничто лестно зде, но вся истина имущим ум от Господа истиннаго. Аминь».

Послание подкреплено одобрительными подписями Аввакума и московского инока Авраамия, получившего «епистолию» тогда же, в конце 1669 г. [2, с. LXIII, $133-136 ; 3$, с. 142].

Что же представлял собой этот неоднозначный ответ дьякона Федора о прежде посвященных и вновь поставленных попах?

После небольшого традиционного вступления, в котором дьякон Федор призывает единоверцев к твердости в вере, он дает обстоятельное разъяснение вопроса, можно ли без вреда для правой веры принять благословение от священника, прежде посвященного, но не устоявшего в вере, затем раскаявшегося и вернувшегося к истине. «...От та-

${ }^{1}$ В рукописи, по которой издан текст (ГИМ, собр. Хлудова, № 260), он назван: «Список с епистолии великих отцев и страдальцев за святую соборную и апостольскую Церковь, еяже должно всякому о Христе живущему прочитати и творити, и да угоден будет Богови, занеже несть ничто лестно зде, но вся истинна имущим ум от Господа истиннаго, Аминь». Н.И. Субботин во введении, кратко характеризуя сочинения 6-го тома, ошибочно идентифицировал Послание с Ответом православных. Авторитетными исследователями старообрядческой литературы XIX в., такими как А.К. Бороздин и П.С. Смирнов, не установлен был адресат письма, «тезоименитый Иоанн» оказался не идентифицированным с определенным историческим лицом.

2 Дьякон Федор упоминает о нем в письме семье Аввакума на Мезень от 1сентября 1669 г. (см.: [4, с. 351-353]). ковых, - поясняет Федор, - достоит благословение приимати и во всем сообщатися, помянувше Петра верховнаго апостола, яко по отречении своем, плача горко, прият Христом бысть и от апостольства не отлучен» [1, с. 63]. Хотя, как рассуждает он далее, и к раскаявшимся священникам можно обращаться только по крайней нужде, при чрезвычайных обстоятельствах, поскольку они нарушили свой долг в отношении веры.

Постоянно же сомневающихся наставников, как уверяет Федор, лучше избегать, лучше обходиться вообще без пастыря. Они, хотя и служат по-старому, но «мыслят двоедушно, егда понуждени будут от отступников к прелести новых догмат, второе и третие отступити хотят, паки вертящеся, яко прах ветром в разуме своем и в неигрательных играти смышляюще: а от таковых, яко от Июды предателя, чуждатися православным, яко на время веруют, и во время напасти отпадают...» [1, с. 63].

Более категорично высказывается дьякон Федор относительно вновь посвященных пастырей, которые «от Никона отступника ставлены и от никониян ... - поставляемии от них попы и дияконы не священи суть, по правилом, вси они отступницы сами и еретицы глупии и поставленнии от них каноному суду подлежат и анафеме. Православным християном ныне не подобает их благословения приимати, ни службы, ни крещения, ни молитвы, и в церкви с ними не молитися, ниже в дому. То есть часть антихристова полка ...» [1, с. 64]. И далее, разъясняя вопрошавшим его единомышленникам, как относиться к священникам, и понимая, какое важное решение он должен принять в это трагическое для всех приверженцев старой веры время, апеллирует к Священному Писанию и с его помощью подкрепляет свои суждения относительно создавшейся ситуации, связанной со священством и авторитетными текстами. Как известно, многие старообрядческие писатели для большей убедительности свои богословские трактовки подкрепляли примерами из ветхозаветной истории, ставили в один ряд исторические события настоящего момента с событиями ветхозаветными. Обращается к этому литературному приему и дьякон Федор. В параллель с никонианскими попами он ставит Вааловых жрецов.

По мнению дьякона Федора, формально всех никонианских попов можно разделить на две категории: на «студных» и «мерзких», в параллель жрецам Ваала, истребленным пророком Ильей ${ }^{3}$. В библейском тексте «студными» названы те жрецы Ваала, которые имели законное священническое достоинство до отпадения

\footnotetext{
${ }^{3}$ См.: III книга Царств, гл. XVIII: 1-40.
} 
от веры царя Ахава ${ }^{4}$, а приминительно к никонианам Федор этот эпитет дает священникам, которые поставлены прежними патриархами до Никона и которые при Никоне приняли его новшества. Точно так же к «мерзким» Федор относит Вааловых жрецов, поставленных тогда, когда Ахав был уже идолопоклонником и в параллель им - никонианских попов, рукоположенных при Никоне, «егда совершенно православие все отринуша древняго предания святых апостол и богоносных отец, и оболгаша их лстивно и охулиша, нечестие же всяко прияша, и оправдаша, и укрепиша, и новоразвращенныя и богомерския книги со многими неисчетными ересми в них похвалиша, и всех еретик крещение римское и священство их гнусное прияша, их же вси святыя отцы наши проклинаша и от святыя церкви отметаша, понеже Рим всех ересей приятелище, источник всякаго нечестия латынское мудрование богомерское» [1, с. 63-64]. От «студных» попов можно принимать всякую святыню, крещение, исповедание, причащение и пр., «непорочнаго ради на них благословения первых наших святых пастырей» $[1$, с. 62]. Это дозволяется по случаю крайней необходимости, так как «лучше тех ныне и невозможно обрести праваго священства» [1, с. 62]. Однако даже при приеме «студных» попов, переходящих из никонианства, надо поступать с известной осторожностью: если они обращаются к «истинной службе» без колебания, вполне искренно, безвозвратно, с готовностью умереть за старое благочестие, то с ними разрешено сообщаться, но следует опасаться таких священников, которые могут по нескольку раз переходить от одних к другим. Что касается попов «мерзких», то они, как поставленные незаконными архиереями, «не священни суть... канонному суду подлежат и анафеме» [1, с. 64], даже если и «по старому служат, отнюдь не подобает благословение приимати, по правилом, ни мало, ни велико: понеже от еретик поставлени не освящени суть, но осквернени от рук их...» [1, с. 75], - так завершает дьякон Федор основные рассуждения об отношении к пастырям настоящего времени - времени, приближающему по его мнению, антихристов приход.

Перед пришествием же в мир антихриста, по убеждениям Федора и судя по эсхатологическим представлениям всех защитников старой веры, должно произойти повсеместное оскудение веры православной. По словам Федора, «в недавнее время совершилось на Руси последнее отпадение от истины. Инаго уже отступления нигде не будет: везде бо бысть, последнее Русь зде. И то от часа сего на горшее происходити будет цари нечестивыми: то суть рози антихристовы, - ими сильно дело все отступническое, без тех же не мощно» [1, с. 66].

${ }^{4}$ Как известно из ветхозаветной истории, израильский царь Ахава по наущению своей нечестивой жены Иезавели стал идолопоклонником. Заметим, что нечестивые цари нередко сравниваются с идолопоклонником Ахавом, можно думать, что его появление на страницах Послания Федора неслучайно, поскольку далее следует его рассуждение о «рогах антихристовых», под которыми подразумеваются нечестивые монархи, в том числе правящий.
Это упоминание о нечестивых царях указывает на некий поворот во взгляде на царя всех защитников «древнего благочестия», которого до сих пор они считали православным, возлагали на него большие надежды; теперь эти представления о правящем монархе резко изменились. В их глазах он был споспешником антихриста. Далее Федор выражается еще более определенно: «Во время се ни царя, ни святителя. Един бысть православный царь на земли остался, да и того не внимающаго себе, западни еретицы, яко облацы темнии, угасили христианское солнце, и свели во тму многия прелести и погрузили, да не возникнет на истинный свой первый свет правды. Увы, увы, бысть!» $[1$, c. 72$]$.

Как видим, Послание Федора было не только откровенным обличением никонианского священства, но оно знаменательно и необычайно смелой для того времени характеристикой «помазанника Божьего». В центре Послания - толкование Федором 13-й главы Апокалипсиса, его рассуждение о «рогах антихристовых». Он вводит более сложное понимание апокалипсических «рогов антихристовых» как царей, с помощью которых будет происходить на Руси «последнее отступление» от веры: «И то от часа сего на горшее происходити будет цари ${ }^{5}$ нечестивыми: то суть рози антихристовы... Два рога от земли исходяща виде Богослов: един от тех есть, вторый же по нем будет, пособитель же злу» $[1$, с. 66].

Такие дерзкие рассуждения дьякона Федора о «рогах антихриста» как о царях, причем не только о ныне правящем монархе, но и о тех правителях, которые последуют за ним, звучат здесь впервые и проводятся им последовательно в дальнейшем во многих сочинениях, касающихся данного вопроса. Эта мысль высказана им и в Письме к семье Аввакума. Пересказывая якобы пророчество некоего суздальского пустынника Михаила ${ }^{6}$, Федор Иванов писал: «Егда седе на царство он (Алексей Михайлович. - Л.Т.) и пришедшии нецыи христолюбцы в пустыню ко святому Михаилу, рабу Божию, и возвестиша ему: «Иной царьгосударь воцарился ныне после отца своего»»). И Михаил рече им: «Несть царь, братие, но рожок антихри-

5 Безоговорочным и наглядным подтверждением того, что не только адресат и адресант осознавали опасность такого категоричного суждения о «рогах антихриста» как о «нечестивых царях», и более того, о правящем царе, но и все единоверцы, которым предназначалось это Послание, служит один из списков XVII в. Послания дьякона Федора Иоанну, где в этом фрагменте текста слово «цари» тщательно выскоблено (см..: РГБ, собр. Ундольского (ф. 310) № 518, л. 9), а в другом списке (ИРЛИ, собр.Карельское, № 550, л. 50 об.) заменено словом «князьми»

${ }^{6}$ К сожалению, письменных данных о пустыннике Михаиле суздальце, практически нет, он упоминается лишь в допросных речах 1666 г. некоего чернеца Савватия (см.: [5, с. 110]). Все же остальные исследователи истории старообрядчества при упоминании Михаила пустынника (отшельника) ссылаются на Письмо дьякона Федора семье Аввакума 1669 г. (см.: [6, с. 324, 333; 7, с. 120, 244-245]). Сам же дьякон Федор в этом Письме сообщает, что о пророчестве суздальского пустынника Михаила узнал от «стража моего темничного, Артемия суздальца» (см.: [4, с. 352]) 
стов». И далее уже рассуждает сам дьякон Федор: «Еже и бысть ныне - видим брань его на Церковь Христову... Да и впредь, братие моя вы о Христе, аз глаголю вам: добра от него не будет Церкви и миру, в том ему и пропасть, в своем лукавстве, не обратен бо...» [4, с. 352]. Из приведенных фрагментов обоих писем совершенно ясно, что под «рогом антихристовым» подразумевается дьяконом Федором царствующий Алексей Михайлович.

Столь резкое обличение царя не обещало ничего хорошего его автору, да и сам Федор трезво оценивал ситуацию. Он прекрасно понимал, какому риску подвергается, поэтому в конце письма неспроста приписал: «А письмо раздерите мое, мучителева ради имени» $[4$, с. 353$]$. Подобное предупреждение сделано было в этом же письме к семье Аввакума и относительно Послания Ивану Аввакумовичу: «А послание, что к тебе писано, брате Иоанне, от меня, и ты того в Соловки и не посылай ... отступником бы не попало: они руку мою знают, и сам рог антихристов знает, знает руку мою. Дела его тако наречют» [4, с. 352]. Опасения дьякона Федора были ненапрасными. Авраамий был арестован в Москве в 1670 г., власти его допрашивали о письмах, изъятых у него при аресте, среди которых были и письма пустозерцев, возможно и Послание к Иоанну Аввакумовичу (на одном из списков Послания есть подпись Авраамия [6, с. 315-316]. Автограф письма дьякона Федора к семье Аввакума попал в Тайный приказ. Некоторые исследователи склонны считать, что «казни» старообрядцев, последовавшие на Мезени и в Пустозерске в конце $1669-$ весной 1670 гг., были реакцией правительства на их обличительные послания.

Следует отметить, что толкование этой же главы Апокалипсиса есть и у Аввакума, но оно заметно отличается от толкования, предложенного дьяконом Федором. У Аввакума истолкование «двух рогов антихриста» иное: «Два же рога у зверя - две власти знаменует: един победитель, а другой - пособитель; Никита, по Алфавиту, или Никон, а другой пособительи - Алексей» [8, с. 224]. Заметим, что в этом тексте Алексею отведена только роль «пособителя», тогда как в толковании дьякона Федора он был представлен основным носителем зла.

Такое истолкование Аввакумом «двух рогов антихриста» как патриарха Никона и царя Алексея было принято частью старообрядцев. Свидетельством этого является создание нового варианта «Послания к некоему Иоанну», которое в списках имеет название: «Выписано из епистолии великих отцев и страдальцев за истинную соборную и апостольскую церковь ис пустозерской темницы» [8, с. 224]. Собственно этот текст представляет собой тщательную выборку из Послания дьякона Федора к Иоанну Аввакумовичу с использованием смягченного Аввакумовского варианта толкования 13-й главы Апокалипсиса ${ }^{7}$. Возможно, это

${ }^{7}$ Подробнее о толковании Аввакумом 13-й главы Апокалипсиса (см.: [9, с. 96-108]). и позволило Н.И. Субботину поместить его в 5-м томе «Материалов для истории раскола...», объединившем сочинения Аввакума, прямых указаний на его авторство в этом Послании не имеется.

Начинается эта версия Послания так же, как и полный федоровский вариант текста - с обращения к адресату: «Брату верному о Господе, благодати тезоименитому Иоанну... и всем верным братиям..» [8, с. 224]. Здесь опущены сведения об авторе (ср.: «Неключимый раб великаго Бога и Спаса нашего Исуса Христа диакон, Божий дар нареченный от крещения, Феодор...» $[1$, c. 60]). Далее Федор призывает единоверцев стоять «неподвижно в вере», несмотря на одолевающие их беды, нужды и скорби, чего нет в компилятивной версии Послания, автор которой сразу же переходит к ответу на главный вопрос, который был задан пустозерским сидельцам, а именно, рассуждениям о священниках, «рукоположенных от прежних православных святителей» и нового поставления.

Автор этой версии умело сокращает ненужные для его замысла подробности источника: так, здесь полностью отсутствуют рассуждения Федора о «мерзских» и «студных» священниках, нет в ней и его размышлений о «лжеучителях». А это одна из самых ярких картин его толкования Апокалипсиса. Федор, призывая «испытывать» Писание «опасно» (тщательно. - Л.Т.), вдумываться в видения «Откровения» Иоанна Богослова. Он пишет о священниках, служащих по-новому, как о лжеучителях, «а лжеучителие настоящаго века сего - кони сатанины, их же виде Иоанн Богослов. Главы у них лвовы, то есть рыкание их зверское являет, и обтичют бо сушу и море, ища вернаго поглотити в прелесть свою. И в хвостах их жало; то есть учение их смертоносное - жало, егоже аще кто приимет прельщенный от них, то жив не будет во веки, умрет душею и телом. А хвост - то лесть знаменует их: прежде бо льстят и обманывают, а потом же мучат не приемлющих в хвостах их жала пагубнаго, сиречь прелести учения их смертоноснаго. Того ради судиша богоноснии отцы каноны своими правильными ничего же от еретик не приимати - ни благословения, ни молитвы» [1, с. 66-67]. Завершается эта версия Послания толкованием этой же 13-й главы протопопом Аввакумом. Ее текст составляет всего одну треть объема Послания Федора.

В настоящее время не представляется возможным назвать автора этой компиляции. Вполне вероятно, что полное текстологическое обследование всех известных в настоящее время списков Послания к Иоанну дьякона Федора (нам в настоящее время известно более 30 его списков), а также компиляции, созданной на его основе (нам известно лишь два ее списка), в дальнейшем позволят прояснить и рукописную судьбу обоих вариантов текста Послания.

Отметим лишь, что автор данной версии Послания отобрал очень экономно материал; осветив самые насущные проблемы староверия - священства и наступления последних времен, прихода в мир антихриста, он соединил две точки зрения на антихриста и его по- 
мощников - Федоровскую, более резкую, и более мягкую Аввакумовскую.

Эти темы оставались долгое время актуальными в старообрядческой среде, оба варианта Послания к Иоанну Аввакумовичу как в выписках, так и полностью очень широко использовались старообрядческими писателями в XVIII в. при составлении полемических сочинений в защиту староверия [10, с. 87-125].

\section{СПИСОК ЛИТЕРАТУРЫ}

1. Материалы для истории раскола за первое время его существования / под ред. Н. Субботина. М. 1881. Т. 6. 336 с.

2. Смирнов П.С. Внутренние вопросы в расколе в XVII веке. СПб., 1898. 237, $121 \mathrm{c}$

3. Бороздин А.К. Протопоп Аввакум: очерк из истории умственной жизни русского общества в XVII веке. СПб., 1900. 175 с.

4. Библиотека литературы Древней Руси. СПб., 2013. Т. 17: XVII век. $661 \mathrm{c}$.

5. Народное антицерковное движение в России XVII века. Документы приказа тайных дел о раскольниках 1665-1667 гг. / сост. В.С. Румянцева. М., 1986. 212 с.

6. Барсков Я.Л. Памятники первых лет русского старообрядчества. СПб., 1912. 389 с.

7. Лукин П.В. Народные представления о государственной власти в России XVII века. М., 2000. 418 с.

8. Материалы для истории раскола за первое время его существования / Под ред. Н. Субботина. М. 1879. Т. 5. 388 с.

9. Демкова Н.С., Титова Л.В. Из литературного наследия пустозерских узников: неизвестная компиляция «Се ныне прииде час искушения на всю вселенную...» // Уральский сборник. История. Культура. Религия. Екатеринбург, 2009. Вып. 7. Ч. 2. С. 96-108

10. Гурьянова Н.С. Сочинения лидеров раннего этапа старообрядческого движения и оформление эсхатологического учения в XVIII в. // Религиозные и политические идеи в произведениях деятелей русской культуры XVI-XXI вв. Новосибирск, 2015. C. $93-125$.

\section{REFERENCES}

1. Materials for the History of Schism during the Early Stage of Its Existence / ed. by N. Subbotin. Moscow, 1881, vol. 6 (In Russ.)

2. Smirnov P.S. The Internal Issues of the Schism in the XVII Century. SPb., 1898 (In Russ.)

3. Borozdin A.K. Archpriest Avvakum. Esseys from the History of Intellectual Life of the Russian Society in the XVII Century (In Russ.)

4. Library of the Old Russian Literature. SPb., 2013, vol. 17: XVII Century (In Russ.)

5. Popular Anti-Church Movement in seventeenth-century Russia. Documents from the Prikaz of Secret Affairs about the Old-Believers, 1665-1667. Comp. by V.S. Rumuantseva. Moscow, 1986, 212 p. (In Russ.)

6. Barskov Ya.L. Monuments of the First Years of the Russian OldBelief. SPb., 1912 (In Russ.)

7. Lukin P.V. Popular beliefs about the state power in seventeenthcentury Russia. Moscow, 2000, 418 p. (In Russ.)

8. Materials for the History of Schism during the Early Stage of Its Existence / ed. by N. Subbotin. Moscow, 1881, vol. 5 (In Russ.)

9. Demkova N.S., Titova L.V. From the literary heritage of the Pustozersk prisoners: unknown compilation "The hour of temptation shall come upon the entire world...". Uralskij sbornik. Istorija. Kultura. Religija. Yekaterinburg, 2009, issue 7, part 2, pp. 96-108 (In Russ.)

10. Guryanova N.S. Writings of the Leaders of the Early Stage of the Old-Believers' Movement and the Formation of the Eschatological Teaching. Religioznyye i politicheskiye idei v proizvedeniyakh deyateley russkoy kultury XVI-XXI vv. Novosibirsk, 2015 (In Russ.)

Статья принята редакиией 04.11.2015 